\title{
Z HISTORII USTALANIA NAZW MIEJSCOWOŚCI NA POGRANICZU POLSKO-UKRAIŃSKIM PO 1945 ROKU
}

\author{
Janusz A. Rieger \\ Uniwersytet Warszawski \\ ORCID: 0000-0002-8160-3596
}

\begin{abstract}
Streszczenie. Administracyjne zmiany ukraińskich i uważanych za ukraińskie nazw miejscowości w Polsce południowo-wschodniej w 1977 roku, późniejsze zabiegi o uchylenie zmian i przywrócenie nazw w 1981 roku były już omawiane. W artykule podano kilka nowych szczegółów oraz omówiono wcześniejsze zmiany przeprowadzone po 1945 roku.
\end{abstract}

Słowa klucze: nazwy miejscowe, zmiany nazw miejscowych, ukraińskie nazwy miejscowe w Polsce

W archiwum domowym zachowałem interesujący protokół z posiedzenia Komisji Ustalania Nazw Miejscowości i Obiektów Fizjograficznych (KUNMiOF) z października 1979 roku, który tu publikuję, a który stanowi punkt wyjścia uwag na temat wskazany w tytule.

Warto tu przypomnieć, że Komisja Ustalania Nazw Miejscowości została powołana w 1934 roku, w 1945 wznowiła działalność (w 1948 zmieniła nazwę na Komisja Ustalania Nazw Miejscowości i Obiektów Fizjograficznych). Komisja odegrała ważną rolę w ujednolicaniu i ustalaniu nazw na ziemiach zachodnich. Nieuniknione z powodu pośpiechu pomyłki nie mogą przysłonić ogromu pracy i rezultatów grupy językoznawcow, historyków i geografów.

Historię i działania Komisji opisywano kilkakrotnie. Jednym z aspektów jej działalności - zbieraniem w terenie nazw miejscowości i nazw fizjograficznych oraz ich publikacją - zajął się Zbigniew Babik ${ }^{1}$. Moje obserwacje uzupełniają w pewnym zakresie jego opracowanie. Zbieranie i opracowywanie nazw w ich brzmieniu miejscowym prowadziło kilka ośrodków akademickich. Gromadząc w latach sześćdziesiątych materiały do monografii o nazwach wodnych dorzecza Sanu, przeglądałem materiały m.in. w ośrodku krakowskim na polonistyce Uniwersytetu Jagiellońskiego. Były to zeszyty z zapisami te-

\footnotetext{
1 Z. Babik, Tzw. akcja UN-owska (1954?-1970?) - Projekt, przebieg, efekty, próba oceny,
} „Onomastica” 2019, t. 63, s. 291-313. 
renowymi i mapy z naniesionymi na nie nazwami. Wypisy z zeszytów i map nanoszono na fiszki. Maszynopisy zawierały nazwy proponowane i zapisy gwarowe. Później poszczególne ośrodki przygotowywały je do druku w zeszytach serii Urzędowe nazwy miejscowości i obiektów fizjograficznych, wydawanych sukcesywnie przez Urząd Rady Ministrów według poszczególnych powiatów. Po likwidacji powiatów w 1975 roku publikację przerwano. Mapy znajdujące się w ministerstwie zniszczono; dowiedziałem się o tym od ówczesnej sekretarz Komisji po fakcie i już nie dało się ich uratować (nie wiem, czy były to oryginały czy kopie map). Później wiele czystopisów przygotowanych do druku, przechowywanych w ministerstwie (pamiętam, że były tam materiały z Poznańskiego opracowane pod kierunkiem Władysława Kuraszkiewicza), zamierzano zniszczyć czy przekazać na makulaturę. Dłuższy czas brałem udział w pracach Komisji jako „ekspert”, a w latach 1989-1997 byłem jej wiceprzewodniczącym, co ułatwiło mi zabranie tych materiałów z ministerstwa; ostatecznie zostały przekazane zespołowi Pracowni Onomastycznej Instytutu Slawistyki PAN (Ewie Rzetelskiej-Feleszko oraz Jerzemu Dumie, który je przewoził autem) - Ewa Wolnicz-Pawłowska pamięta, że stało się to w latach dziewięćdziesiątych XX wieku. W moim przekonaniu oryginały lub co najmniej kopie tych materiałów powinny były znajdować się tam, gdzie je opracowano, tzn. w Poznaniu. Chyba na przełomie XX i XXI wieku pytałem w Krakowie o brudnopisy i o mapy i uzyskałem informację, że są przechowywane „na strychu” w gmachu przy ul. Gołębiej. Warto pamiętać, że zebrane materiały w zakresie nazw fizjograficznych znacznie przekraczają liczbę nazw opublikowanych, bo tu dawano je - z konieczności - tylko w wyborze. Patronując zbieraniu materiałów terenowych i opracowaniu Urzędowych nazw miejscowości... KUNMiOF odegrała pozytywną rolę, niezależnie od różnych mankamentów wskazanych m.in. przez Z. Babika; nieco gorzej wypada ocena ustalania nazw na pograniczu polsko-ruskim (por. niżej krytyczne uwagi do niektórych nazw na ziemiach południowo-wschodnich).

Działalność Komisji w zakresie ustalania nazw miejscowości na pograniczu wschodnim w latach siedemdziesiątych opisali w zarysie Stanisław Urbańczyk w 1981 roku$^{2}$ oraz Kazimierz Rymut w 2003 roku$^{3}$, por. też artykuł Jacka Wysockego z 2010 roku $^{4}$ Trzeba podkreślić zdecydowanie Komisji pod przewodnictwem Witolda Taszyckiego (działającej wówczas przy Prezesie Rady Ministrów) w odrzuceniu projektu zamiany tysiąca kilkuset nazw miejscowo-

\footnotetext{
2 S. Urbańczyk, Zmiana nazw w Polsce poludniowo-wschodniej, „Język Polski” 1981, t. 41, z. 3-5, s. 233-238.

K. Rymut, Działalność Komisji Ustalania Nazw Miejscowości i Obiektów Fizjograficznych w latach 1978-2003, „Onomastica” 2003, t. 48, s. 315-324.

J. Wysocki, Próby zmian nazw miejscowości na Lubelszczyźnie w latach siedemdziesiatych XX w., „Przegląd Archiwalny Instytutu Pamięci Narodowej” 2010, s. 285-318 (tamże dalsza literatura).
} 
ści o brzmieniu białoruskim i ukraińskim na polskie lub „spolszczone”. Jak informował S. Urbańczyk, projekt przedstawiło Ministerstwo Spraw Wewnętrznych na wniosek wojewodów w 1974 roku; sprzeciw Komisji w tymże roku go zablokował. Ale kompetencje ustalania nazw przeniesiono do Ministerstwa Administracji, Gospodarki Terenowej i Ochrony Środowiska, de facto likwidując Komisję. Sprawa zmiany nazw wróciła w Ministerstwie w 1977 roku. Pod koniec tego roku zarządzeniem opublikowanym w Monitorze Polskim z 1977 roku (nr 21, poz. 112) w południowo-wschodniej Polsce zmieniono 120 nazw (wcześniej, bo wiosną tego roku zarządzeniem w MP nr 6, poz. 44 zmieniono 2 nazwy: Rabe koło Baligrodu na Karolów, Htomcza w gminie Sanok na Świerczewo ${ }^{5}$ ). Na nic się zdały ostre protesty środowisk inteligenckich: przewodników górskich, Związku Literatów Polskich, Komitetu Nauk Historycznych PAN pod przewodnictwem Stefana Kieniewicza ${ }^{6}$. Profesor S. Urbańczyk przypomina, że w 1978 roku przywrócono KUNMiOF, a jej przewodniczącym został Mieczysław Szymczak ; Komisja podjęła działalność 13 czerwca tego roku, wtedy to ,,przedstawiciel Ministerstwa powiadomił od razu, że kierownictwo resortu liczy się z koniecznością uchylenia pewnej liczby nowych nazw, mniej więcej jednej czwartej. Lista ich została ustalona. Oczywiście była to tylko propozycja, kierowana do ministra, ponieważ komisja jest ciałem tylko doradczym". S. Urbańczyk pisze, że przewodniczący Komisji miał interweniować w Ministerstwie (daty i zakresu tej interwencji nie podaje). Z załączonego tu protokołu z posiedzenia z 8 października 1979 roku dowiadujemy się, że

\footnotetext{
5 W roku 1981 przywrócono stare nazwy Rabe i Hłomcza razem z innymi nazwami.

6 Protest Komitetu Językoznawstwa PAN, uchwalony na posiedzeniu w dn. 19 grudnia 1977 roku, brzmiał słabo, por. J. Rieger, Z historii Komitetu Językoznawstwa PAN (1952-2002), „Prace Filologiczne” 2014, t. 65, s. 339-358; tu zob. s. 349-350. Wskazano tam m.in. obecność dawnych nazw niepolskiego pochodzenia, które mają „,w polskiej historii, literaturze i - szerzej rzecz ujmując - polskiej kulturze pozycję trwałą, ugruntowaną tradycją, często wielowiekową [...]”. I dalej: „Zmieniać w nazewnictwie można tylko to, co rzeczywiście konieczne, ale niepodobna czynić to bez zasięgania opinii kompetentnych instytucji grupujących językoznawców, a także historyków i geografów. Opinia poszczególnych osób nie może w tym przypadku wystarczyć”. Dalej pokazano aktualność tych rozważań: „Uwagi powyższe odnieść należy również do Zarządzenia [...] w sprawie zmiany niektórych miejscowości [...]. W wyniku Zarządzenia zmieniono nazwy na ogół dawne, notowane w źródłach historycznych często od XIV-XV w., m.in. Młodowice, Kobylnica, Koniusza. Szereg tych nazw świadczy o dawnym przenikaniu kultur [...]”. Wreszcie stwierdzono, że „Komitet Językoznawstwa PAN uważa za niezbędne ożywienie działalności i odnowienie składu Komisji Ustalania Nazw Miejscowości i Obiektów Fizjograficznych przy Urzędzie Rady Ministrów. Komitet uważa również za konieczne ustalenie i respektowanie ustawowych uprawnień wymienionej Komisji" (cytuję za odpisem uchwały z domowego archiwum).

Według informacji podanych przez S. Urbańczyka i K. Rymuta zastępcą przewodniczącego został Przemysław Zwoliński, a członkami z językoznawców - K. Rymut, S. Urbańczyk, A. Zaręba, z historyków - Henryk Samsonowicz, Stanisław Trawkowski, Jerzy Wiśniewski; w skład Komisji wchodzili także przedstawiciele urzędów i wojska.
} 
wcześniej Komisja wnioskowała o przywrócenie dawnych nazw tylko 47 miejscowościom (co potwierdza informację S. Urbańczyka), a Ministerstwo zaakceptowało „większość propozycji”, zaproponowało jednak o odstąpienie od przywrócenia 14 nazw (a więc mniej więcej jednej trzeciej z wcześniejszej jednej czwartej!) z niesprecyzowanych bliżej przyczyn ,natury społeczno-politycznej”. Chodziło o nazwy: Lisówek (dawn. Liskowate), Łąka (Ulucz), Łęgi (Lodyna), Łukasiewicze (Stuposiany), Miodowa (Lachawa), Nowa Wieś (Uherce Mineralne), Roztoka (Wolosate), Sanniki (Sianki), Boguszów (Werchrata), Podlesie (Kniażyce), Pogoń (Iskań), Walterów (Mtodowice), Witoldów (Aksmanice), Witoldówek (Jaksmanice). Przyczyny polityczne były jasne tylko w przypadku nazwy Walterów - na cześć gen. Karola Świerczewskiego „Waltera”, oraz Witoldów i Witoldówek - niewątpliwie na cześć gen. Franciszka Jóźwiaka „Witolda”, który w latach 1945-1949 był wiceministrem bezpieczeństwa publicznego. Komisja ,jednomyślnie przyjęła zgłoszony wniosek"». Nowy skład Komisji okazał się więc - mówiąc oględnie - mniej stanowczy niż poprzedni tak we wcześniejszym wniosku o przywrócenie tylko części dawnych nazw, jak i w dalszym ograniczeniu swoich propozycji przedstawionym w cytowanym protokole; czym było to uwarunkowane, już się nie dowiemy. Dopiero po 1980 roku protesty wybuchły na nowo, przywrócenie dawnych nazw było jednym z postulatów strajku chłopskiego w Ustrzykach Dolnych. Na konferencji prasowej w Ministerstwie 31 stycznia 1981 miały paść słowa o gotowości resortu do wycofania się z krytykowanej zmiany, a 2 lutego odbyło się zebranie Komisji w obecności prasy, na której członkowie Komisji udzielili informacji o rozwoju wydarzeń od 1974 roku. Zarządzenie uchylające zmiany dawnych nazw ukazało się w Monitorze Polskim nr 7 z 27 lutego 1981.

Zmiany nazw ukraińskich na polskie dokonywane były jednak wcześniej ${ }^{9}$. Nie wiemy też, jaką rolę odegrała tu Komisja Ustalania Nazw Miejscowości, a Urzędowe nazwy miejscowości (ich redaktorem był Witold Taszycki) były, z jednej strony, firmowane przez Komisję, a z drugiej - przez Urząd Rady Ministrów, co nadawało im charakter oficjalny, zwłaszcza że były opatrzone klauzulą „do użytku służbowego” (por. załączone facsimile). Stanowią one często pierwsze źródło dla ,poprawionych” nazw ${ }^{10}$. W roku 1966 pisałem o Berehach

\footnotetext{
8 Głosowali tylko obecni na posiedzeniu członkowie Komisji (w protokole wskazano przewodniczącego; pamiętam, że obecni byli jeszcze P. Zwoliński i S. Urbańczyk); zaproszeni goście, a więc „eksperci” wskazani na początku protokołu, nie mieli prawa głosu.

9 Z czego zdawali sobie sprawę językoznawcy zajmujący się nazewnictwem tych obszarów, wspomina o tym w cytowanym wyżej artykule J. Wysocki, powołując się na na pracę S. Kłosa, Bieszczady (Wrocław 2000, s. 157).

10 Cyt. za Nazwy miejscowe Polski. Historia, pochodzenie, zmiany, red. K. Rymut, Kraków 1996 i n. Chyba nie zawsze publikacje Urzędowych nazw miejscowości... poprzedzało zarządzenie publikowane w Monitorze Polskim (w MP z lat 1965 i 1966 nie znalazłem takiego zarządzenia).
} 
Górnych i Dolnych ${ }^{11}$; w tym samym roku w Urzędowych nazwach miejscowości pojawiły się na ich miejsce Brzegi Górne i Dolne (przy czym zeszyt UN wyprzedził o dwa lata zmianę wprowadzoną w Monitorze Polskim zarządzeniem nr 17 z 05.02.1968). Również w 1966 roku nazwa wsi Czystohorb koło Komańczy została zmieniona na Czystogarb. Rok wcześniej, tj. w 1965 roku nazwa Krywa koło Cisnej na Krzywa, nazwa Strubowiska tamże na Strzebowiska (UN 61) itd. Brak postulatów wycofania się z kilku zmian jest jasny: w większości przypadków były to wsie wyludnione w ramach powojennych przesiedleń na Ukrainę oraz w ramach akcji „Wisła” na ziemie zachodnie, jak np. Berehy Górne czy Krywe, a Berehy Dolne wróciły do Polski w ramach zmian granicznych w 1951 roku opustoszałe i zostały zasiedlone przez ludność polską. Oburzali się więc co najwyżej turyści czy językoznawcy slawiści zajmujący się tymi terenami. Podobnie w nazwach terenowych z zapisu w terenie śinožatki - chodzi o ukraińską wersję sianożęci, zrobiono oficjalne Sianorządki (tak było w wersji projektowanej czy w ostatecznej - nie potrafię powiedzieć), z pohar 'pogorzelisko' zrobiono Pogar itd. O podobnych zabiegach ,polonizacyjnych" na Podlasiu pisał m.in. Michał Kondratiuk ${ }^{12}$.

Jeszcze wcześniej, bo w 1949 roku (czy bez pytania Komisji?) zamieniono Uście Ruskie na Uście Gorlickie ${ }^{13}$, Krywa koło Gładyszowa na Krzywą, Ruska Wieś k. Dubiecka na Brzeżynę, Smerekowiec na Smrekowiec, Ropice Ruska nad rzeką Ropicą (tak m.in. na mapach przedwojennych) na Ropice Górna ${ }^{14}$; przy okazji Ropice Polska nad rzeką Ropą, oddzieloną od Ropicy Górnej działem wodnym, zamieniono jednocześnie na Ropice Dolna - chyba dla symetrii. Też w 1949 roku na terenach zamieszkanych przez Łemków zmieniono niemiecką z pochodzenia nazwę Rychwald na Owczary ${ }^{15}$, koło Jasła Glinik Niemiecki zamieniono na Nowy Glinik, a w okolicach Lubaczowa nazwy części wsi Deutschbach i Felsendorf na Polanka Horyniecka i Dąbków. W roku 1957 zamieniono w pow. przemyskim Hujsko (dawn. Osko, Ojsko, Wujsko, ukr. Wijsko, Hijsko ${ }^{16}$ ) na Nowe Sady ${ }^{17}$, a Lutowiska na Szewczenko $^{18}$.

11 J. Rieger, Z Toponomastyki bojkowskiej i temkowskiej. 8. Berehy Zapołonińskie (Górne), Berehy Stuposiańskie (Bereżki) i Berehy Dolne, „Slavia Orientalis” 1996, t. 15, nr 3, s. 299-300.

12 M. Kondratiuk, Urzędowe i gwarowe nazwy miejscowości Białostocczyzny, Białystok 2011.

13 Por. Nazwy miejscowe Polski...

14 W Internecie wspominana jest też powojenna nazwa sprzed 1949 roku: Ropica Sękowska (od nazwy sąsiedniej wsi Sękowa), ale bez podania źródła.

15 Monitor Polski nr A-54, poz. 975, rozporządzenie Ministra Administracji Publicznej z 19.08.1949 [korzystam z wersji MP online ISAP = Internetowy System Aktów Prawnych].

16 Według Władysława Makarskiego od osa 'osika', zob. W. Makarski, Nazwy miejscowe dawnej ziemi przemyskiej, Lublin 1999, s.187.

17 Zamiast np. na Wujsko (bo $h$ - i $w$-są tu ukraińskimi protezami).

18 Monitor Polski nr 51, poz. 322 z 24.06.1957. 
Wygląda na to, że zarządzenia władz, poblikowane w Monitorze Polskim, oraz zmiany dokonywane przez UN-y, szły czasem odrębnymi ścieżkami. Pisałem wyżej o Berehach Górnych występujących w UN jako Brzegi Górne od 1966 roku, ale w zarządzeniu publikowanym w MP dopiero od 1968 roku. Tym też zarządzeniem zmieniono m.in. nazwę Hyrowa (forma łemkowska Hblrowa, nazwa niejasna ${ }^{19}$ ) na Chyrowa, Bachlowa (forma łemkowska $\mathrm{Ba}$ chłowa) na Bachlawa, Manasterzec (nazwa od XVI wieku) na Monasterzec (od 1981 roku znów Manasterzec) ${ }^{20}$ - wszystkie te nazwy w nowej postaci w UN-ach występują już od 1965 roku $^{21}$

Jak wskazywano już w wielu oświadczeniach i publikacjach, zabiegi „polonizacyjne" w zakresie nazewnictwa miejscowości i obiektów fizjograficznych świadczą o braku zrozumienia dla naszego dziedzictwa kulturowego, o lekceważeniu nie tylko tego dziedzictwa, ale także praw mniejszości, świadczą też o fałszywym pojmowaniu interesu narodowego.

\section{BIBLIOGRAFIA}

Babik Zbigniew. 2019. Tzw. akcja UN-owska (1954?-1970?) - Projekt, przebieg, efekty, próba oceny. „Onomastica” 63: 291-313 [tamże literatura].

Kondratiuk Michał. 2011. Urzędowe i gwarowe nazwy miejscowości Białostocczyzny, Białystok: Białoruskie Towarzystwo Historyczne.

Makarski Władysław. 1999. Nazwy miejscowe dawnej ziemi przemyskiej. Lublin: Towarzystwo Naukowe KUL.

Rieger Janusz. 1996. Z toponomastyki bojkowskiej i łemkowskiej. 8. Berehy Zapołonińskie (Górne), Berehy Stuposiańskie (Bereżki) i Berehy Dolne. „Slavia Orientalis” 15, nr 3: 299-300.

Rieger Janusz. 2014. Z historii Komitetu Językoznawstwa PAN (1952-2002). „Prace Filologiczne" 65: 339-358.

Rymut Kazimierz. 2003. Działalność Komisji Ustalania Nazw Miejscowości i Obiektów Fizjograficznych w latach 1978-2003. „Onomastica” 48: 315-324.

Rymut Kazimierz (red.). 1996 i n. Nazwy miejscowe Polski. Historia, pochodzenie, zmia$n y$, t. 1 i n. Kraków: Instytut Języka Polskiego PAN.

Stieber Zdzisław. 1948. Toponomastyka Łemkowszczyzny, cz. : Nazwy miejscowości. Łódź: Łódzkie Towarzystwo Naukowe.

Urbańczyk Stanisław. 1981. Zmiana nazw w Polsce poludniowo-wschodniej. ,Język Polski”" t. 41, z. 3-5: 233-238.

Wysocki Jacek. 2010. Próby zmian miejscowości na Lubelszczyźnie w latach siedemdziesiatych $X X$ w. „, Przegląd Archiwalny Instytutu Pamięci Narodowej” nr 3: 285-318 [tamże dalsza literatura].

19 Formy łemkowskie podaję za: Z. Stieber, Toponomastyka Łemkowszczyzny, cz. I: Nazwy miejscowości, Łódź 1948.

20 Monitor Polski, zarządzenie nr 17 z 05.02.1968.

${ }^{21}$ Wskazywane w UN-ach postaci gwarowe typu Chyrowa czy Bachlawa są zapewne autentyczne, ale niewątpliwie nowe, mogące polegać na przekręceniu nazwy przez polskich osadników. 


\title{
SOME REMARKS ON THE CHANGES OF PLACE NAMES IN THE POLISH-UKRAINIAN BORDERLANDS AFTER 1945
}

\begin{abstract}
In 1977 Polish government renamed 122 places names in southeasth Poland, replacing place names of Ukrainian origin (in fact part of them were actually of Polish origin) with new, Polish ones. Thanks in part to the efforts of the Solidarity movement the changes were reverteded in 1981 . The paper presents some new details concerning the efforts made for the restitution of the old place names and discusses earlier changes to place names of Ukrainian origin made after 1945.
\end{abstract}

Key words: place names, Ukrainian place names in Poland, changes of place names

\section{ДО ІСТОРІЇ ОФІЦІЙНОГО ІМЕНУВАННЯ НАСЕЛЕНИХ ПУНКТІВ НА ПОЛЬСЬКО-УКРАЇНСЬКОМУ ПОГРАНИЧЧІ ПІСЛЯ 1945 РОКУ}

Анотація. Адміністративні зміни українських і таких, що вважалися українськими, назв населених пунктів у Південно-Східній Польщі в 1977 році, пізніші заходи, що мали на меті скасування цих змін і повернення назв у 1981 році, вже були обговорені. У статті подано кілька нових подробиць, а також обговорено більш ранні зміни, запроваджені після 1945 року.

Ключові слова: ойконіми, зміни назв населених пунків, українські ойконіми в Польщі 
